\title{
REGULASI RESEPTOR CYTOTOXIC T LYMPHOCYTE ASSOCIATED PROTEIN 4 LIMFOSIT T TERHADAP KANKER DAN AUTOIMUN: LITERATURE REVIEW
}

\author{
Rian Anggia Destiawan*1, Anas Fadli Wijaya ${ }^{2}$, M. Elyas Arif \\ Budiman $^{3}$, Septyana Eka Rahmawati ${ }^{4}$ \\ ${ }^{1}$ Fakultas Ilmu Kesehatan, Universitas dr. \\ Soebandi \\ ${ }^{2}$ Fakultas Ilmu Kesehatan, Universitas dr. \\ Soebandi \\ ${ }^{3}$ Fakultas Ilmu Kesehatan, Universitas dr. \\ Soebandi \\ ${ }^{4}$ Sekolah Pascasarjana, Universitas Airlangga \\ *1e-mail : rianad@uds.ac.id \\ 2e-mail : anasfw@uds.ac.id
}

\begin{abstract}
Cytotoxic T Lymphocyte Associated Protein 4 (CTLA-4) is a T lymphocyte receptor that binds to the B7-1 and B7-2 of dendritic cells. CTLA-4 inhibits the work of T lymphocytes. CTLA-4 is expressed by Tymphocytes at rest or after activation. CTLA-4 is found in dendritic cells, monocytes, B lymphocytes, T lymphocytes, granulocytes, and CD34+ stem cells. CTLA-4 plays an important role in tumor development, cancer and autoimmune disease. This review literature aims to discuss the regulation of CTLA-4 T lymphocytes against cancer and autoimmune diseases. Method: systematic search on three databases namely NCBI, science direct, and nature with the keyword "CLTA-4 and T cell and cancer and autoimmune" in 2021. Results: 6 intervention options to reduce CTLA-4 expression and 1 intervention to improve CTLA-4 expression. Conclusion: Based on an analysis of 7 research articles, decreased CTLA-4 expression can inhibit cancer growth and increased CTLA-4 expression can inhibit the development of autoimmune.
\end{abstract}

Keywords: CTLA-4, T lymphocytes, Cancer, and Autoimmune

\section{Abstrak}

Cytotoxic T Lymphocyte Associated Protein 4 (CTLA-4) adalah reseptor limfosit T yang berikatan dengan B7-1 dan B7-2 dari sel dendritik. CTLA-4 berperan menghambat kerja limfosit T. CTLA-4 diekspresikan oleh limfosit $\mathrm{T}$ pada fase istirahat atau setelah teraktivasi. CTLA-4 ditemukan pada sel dendritik, monosit, limfosit B, limfosit T, granulosit, dan stem sel CD34+. CTLA-4 berperan penting dalam perkembangan tumor, kanker serta autoimun. Literatur review ini bertujuan untuk membahas regulasi CTLA-4 limfosit T terhadap penyakit kanker dan autoimun. Metode: pencarian sistematis pada tiga database yaitu NCBI, science direct, dan nature dengan kata kunci "CLTA-4 and T cell and cancer and autoimmune" tahun 2021. Hasil: didapatkan 6 pilihan intervensi untuk mengurangi ekspresi CTLA-4 dan 1 intervensi untuk meningkatkan ekspresi CTLA-4. Kesimpulan: berdasarkan analisis terhadap 7 artikel penelitian, penurunan ekspresi CTLA-4 dapat menghambat pertumbuhan kanker dan peningkatan ekspresi CTLA-4 dapat menghambat berkembangnya autoimun maka dapat.

Kata Kunci: CTLA-4, Limfosit T, Kanker, dan Autoimun.

\section{PENDAHULUAN}

Kanker dan autoimun merupakan penyakit yang disebabkan karena terjadinya abnormalitas secara genetik. Kanker merupakan penyakit yang disebabkan abnormalitas pada genetik dan epigenetik, abnormalitas tersebut menyebabkan terjadinya proliferasi sel yang terus menerus (Khan et al., 2021). Autoimun adalah 

penyakit yang disebabkan karena abnormalitas sistem imunitas menyerang jaringan tubuh sendiri sehingga terjadi kerusakan atau disfungsi organ. Abnormalitas ini disebabkan karena faktor genetik, lingkungan, dan infeksi yang terus menerus (Xiao et al.,2021).

Sel imunitas adaptif yang berperan untuk menekan terjadinya penyakit adalah sel limfosit, salah satunya limfosit T. Limfosit T dibagi menjadi dua yaitu limfosit $\mathrm{T} \mathrm{CD} 8^{+}$ (limfosit $\mathrm{T}$ sitotoksik) dan limfosit $\mathrm{CD} 4^{+}$ (limfosit T Helper). Limfosit T memiliki dua sifat reseptor yaitu costimulator dan inhibitor yang berperan dalam meregulasi kerja dari limfosit T. reseptor yang bersifat costimulator adalah CD28 dan ICOS, berperan dalam mestimulasi sel $\mathrm{T}$ menjadi aktif, reseptor yang bersifat coinhibitor adalah CTLA-4, PD-1, BTLA, TIGIT), berperan dalam menghambat kerja sel T (Karimi et al., 2021; Rowshanravan et al., 2018).

Penyakit kanker dan autoimun dapat ditekan dengan meregulasi salah satu reseptor limfosit $\mathrm{T}$ yaitu Cytotoxic $T$ Lymphocyte Associated Protein 4 (CTLA4). Cytotoxic $T$ Lymphocyte Associated Protein 4 (CTLA-4) adalah reseptor yang berfungsi sebagai immune checkpoint dengan fungsi sebagai coinhibitor (Tiemann et al., 2021). Penulisan Literature Review ini bertujuan untuk membahas tentang regulasi CTLA-4 limfosit $\mathrm{T}$ terhadap penyakit autoimun dan kanker.

\section{METODE}

Desain penelitian ini adalah dengan mengidentifikasi jurnal penelitian 1 tahun terakhir dari tahun Januari 2021 sampai Desember 2021. Jurnal penelitian yang direview adalah regulasi CTLA-4 limfosit T terhadap kanker dan autoimun (penurunan CTLA-4 limfosit T pada penyakit kanker dan peningkatan CTLA-4 limfosit $\mathrm{T}$ pada penyakit autoimun).

\subsection{Metode Seleksi Artikel}

Kriteria beberapa inklusi pada penelitian ini adalah 1) artikel yang di review pada penelitian ini berkaitan dengan penurunan CTLA-4 limfosit T pada penyakit kanker dan peningkatan CTLA-4 limfosit T pada penyakit autoimun dengan pendekatan true eksperimental, metode penelitian ini melalui Randomized Controlled Trial (RCT) atau uji acak terkontrol. 2) Populasi dalam artikel review adalah manusia, mencit (Mus muscullus), atau tikus (Rattus novergicus) yang mengalami kanker dan autoimun dengan parameter CTLA-4 limfosit T. 3) menggunakan intervensi famakologis ataupun non farmakologis pada penyakit kanker dan autoimun dengan meregulasi CTLA-4 pada limfosit T.

Kriteria eksklusi pada penelitian ini adalah tidak ada hubungan antara terapi dengan peningkatan atau penuruan CTLA-4 limfosit $\mathrm{T}$, tidak mencantumkan hasil yang diperoleh, dan jurnal terbit sebelum 2021.

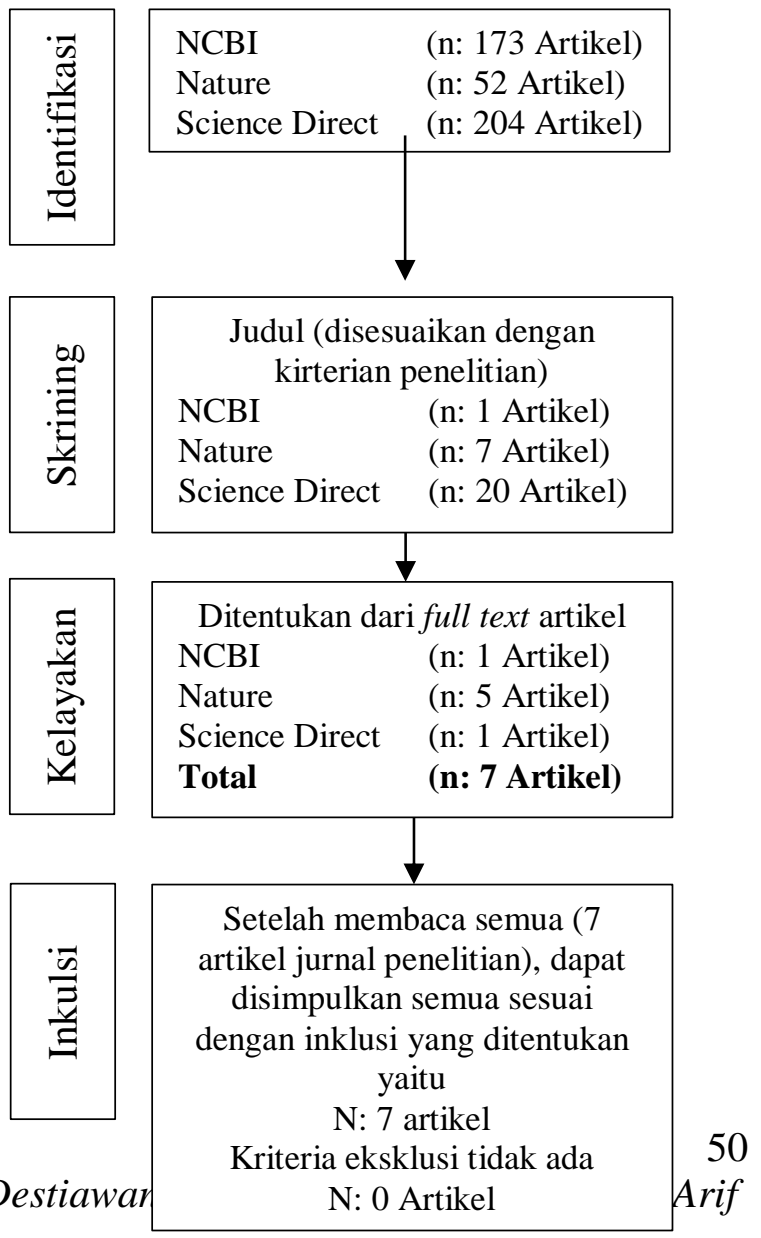




\section{HASIL PENELITIAN}

Gambar 1. Proses pencarian literatur

\subsection{Metode Pencarian Artikel}

Metode pencarian artikel pada penelitian ini ditinjau secara sistematis yaitu mulai dari menetukan topik penelitian serta membuat kata kunci untuk mencari jurnal menggunakan bahasa inggris. Pencarian jurnal dilakukan melalui tiga database yaitu NCBI, Nature, dan Science direct dalam rentang 1 tahun dimulai dari Januari 2021 sampai Desember 2021. Kata kunci bahasa inggris yang digunakan adalah "CTLA-4 and $T$ cell and Cancer and Autoimmune". Kemudian, dilakukan identifikasi judul dari setiap artikel yang mendekati penelitian yang kita inginkan. Kemudian dilakukan indentifikasi abstrak dan isi keseluruhan jurnal untuk mendapatkan hasil penelitian yang sesuai dengan keinginan peneliti.

Hasil pencarian pada tiga database tersebut, menemukan pada database NCBI terdapat 173 artikel, Nature terdapat 51 artikel, dan Science direct terdapat 204 artikel. Total semua artikel yang ditemukan adalah 428 artikel. Setelah dilakukan penyaringan judul artikel, didapatkan 28 delapan judul yang dianggap relevan dengan penelitian ini. Kemudian peneliti menyaring lagi dengan membaca semua artikel tersebut yang dihubungkan dengan kriteria inklusi, didapatkan 7 artikel yang relevan dan sesuai dengan kriteria inklusi. Artikel-artikel tersebut tidak memliki faktor eksklusi.

\subsection{Studi Analisis}

Artikel yang diperoleh dan sesuai dengan metode randomized controlled trial (RCT) kemudian disesuaikan dengan tujuan penelitian.
Berdasarkan penelitian yang telah dilakukan dengan melihat berbagai populasi, terdapat 7 artikel yang memenuhi kriteria inklusi. Berbagai jenis terapi/pengobatan digunakan dalam pengobatan kanker dan autoimun, diantaranya menggunakan pengobatan antibodi monoklonal, dan menggunakan obat-obat kimia. Intervensi atau pengobatan yang digunakan pada penelitian ini menggunakan beberapa intervensi/pengobatan

Berbagai macam terapi digunakan untuk menurunkan kejadian kanker dan autoimunitas, dan terapi tersebut sangat berdampak pada penderita kanker dan autoimun. Pada penderita kanker beberapa terapi yang digunakan adalah antibodi anti CTLA-4 digunakan untuk menghambat pertumbuhan tumor dan kanker. Modifikasi epigenetik yaitu N6-methyladenosine (m6A) yang digunakan untuk menghambat terjadinya lung adenocarcinoma. Tremelimumab digunakan untuk menghambat pertumbuhan metastatic renal cell carcinoma. Ipilimumab digunakan untuk menghambat pertumbuhan leptomeningeal carcinomatosis. Pembrolizumab berperan dalam menghambat metastasis tumor, dan anti CTLA-4 ipilimumab dan NY-ESO-1 berperan dalam menghambat metastasis melanoma. Sedangkan pada penderita autoimun dapat menggunakan terapi Growth and Diferentiation Factor 7 (GDF-7), Interleukine-10 (IL-10), dan Interferon alpha 7 (IFNa-7), terapi tersebut dalam menurunkan kejadian autoimunitas (Brastianos et al., 2021; Campbell et al., 2021; Cindy Yang et al., 2021; Ding et al., 2021; Slingluff et al., 2021; Tian et al., 2021; Wu and Bai, 2021).

Berdasarkan data diatas, Obat atau terapi pada kanker merupakan terapi yang menghambat ekspresi CTLA-4 pada limfosit T, CTLA-4 merupakan reseptor yang dimiliki oleh limfosit $\mathrm{T}$ untuk menghambat kerja dari 
limfosit T. Sehingga, menurunnya ekspresi CTLA-4 pada limfosit $\mathrm{T}$ menyebabkan limfosit $\mathrm{T}$ akan aktif untuk menghambat pertumbuhan tumor dan kanker. Berbeda dengan kanker, pada penyakit autoimunitas, obat atau terapi yang digunakan adalah obat yang meningkatkan ekspresi CTLA-4. Meningkatnya ekspresi CTLA-4 akan menghambat respon dari sel limfosit $\mathrm{T}$, menyebabkan menurunnya kerja dari limfosit $\mathrm{T}$.

\section{PEMBAHASAN}

Reseptor yang berperan penting terhadap penyakit kanker dan autoimun adalah reseptor CTLA-4 yang bersifat inhibitor. Kanker memanfaatkan reseptor CTLA-4 untuk berkembang. CTLA-4 akan berikatan dengan CD80 dan CD86 (CTLA4;CD80 dan CTLA-4:86) pada antigen presenting cell (APC). Ikatan tersebut lebih kuat dibandingkan dengan CD28 (yang merupakan kostimulator) dengan CD80 dan CD86 (CD-28:CD80 dan CD28:Cd86) pada antigen presenting cell (APC), ikatan tersebut menyebabkan terjadinya imunosupresif dan menghambat kerja limfosit T (Sobhani et al., 2021).

Terapi yang digunakan di atas bertujuan untuk menurunkan atau menekan proliferasi kanker adalah dengan cara menghambat atau memblok ekspresi CTLA4 pada limfosit $\mathrm{T}$ sehingga membatasi ikatan antara CTLA-4 dengan CD80 dan CD 86 (CTLA-4:CD80 dan CTLA-4:86) yang menyebabkan menurunnya respon imunosupresif. Menurunnya respon imunosupresif dapat meningkatnya respon imunitas limfosit $\mathrm{T}$ sehingga terjadi infiltrasi sel limfosit $\mathrm{T}$ helper $\left(\mathrm{CD}^{+}\right)$dan limfosit $\mathrm{T}$ $\left(\mathrm{CD}^{+}\right)$serta dan menurunnya limfosit $\mathrm{T}$ regulator (Limfosit Treg) di lingkungan tumor dan kanker (Sugawara et al., 2021).

Berbeda dengan tumor dan kanker. Pada penyakit autoimunitas terjadi penurunan ekspresi reseptor CTLA-4 yang disebabkan karena mutasi CTLA-4. Menurunnya ekspresi CTLA-4 menyebabkan terjadi penurunan ikatan dengan CD80 dan CD86 (CTLA-4:CD80 dan CTLA-4:86) pada sel antigen presenting cell (APC), dan meningkatnya ikatan reseptor CD28 dengan CD80 dan CD86 (CD-28:CD80 dan CD28:Cd86) yang bersifat kostimulator. Kejadian tersebut menyebabkan penurunan respon penekanan sistem imun (imunosupresif), terjadinya peningkatan respon imunitas yang tidak terkontrol, serta menurunnya limfosit $\mathrm{T}$ regulator (menekan kerja dari limfosit $\mathrm{T}$ supaya tidak berlebihan), hal tersebut menyebabkan kegagalan homeostasis sistem imunitas (Gámez-Díaz and Grimbacher, 2021; Tiemann et al., 2021).

Terapi yang digunakan di atas bertujuan untuk meningkatkan reseptor CTLA-4 sehingga terjadi peningkatan ikatan dengan CD80 dan CD86 (CTLA-4:CD80 dan CTLA-4:86) pada sel antigen presenting cell (APC). Peningkatan ikatan tersebut dapat menurunkan infiltrasi proliferasi limfosit $\mathrm{T}$ (Dong et al., 2021). Selain itu, meningkatnya limfosit $\mathrm{T}$ regulator, serta dapat meningkatkan homeostasis sistem imunitas, sehingga dapat menekan kerja limsofit $\mathrm{T}$ pada penderita autoimunitas

\section{KESIMPULAN}

Penelitian ingin menggambarkan bahwa penyakit kanker dan autoimun memiliki mekanisme terapi yang berbeda. Pada penyakit kanker terapi yang digunakan adalah terapi yang dapat menekan reseptor CTLA-4 yang bersifat koinhibitor sehingga dapat meningkatkan reseptor CD28 yang bersifat kostimulator, sedangkan pada penyakit autoimun, terapi yang digunakan adalah terapi yang dapat meningkatkan reseptor CTLA-4 yang bersifat koinhibitor, sehingga dapat menekan CD28 yang bersifat kostimulator dan meningkatkan CTLA-4 yang bersifat koinhibitor, sehingga akan 
(C) (2021) Sekolah Pascasarjana Universitas Airlangga, Indonesia

tercapai homeostasis sistem imunitas dalam tubuh.

\section{UCAPAN TERIMAKASIH}

Terimakasih kepada seluruh tim penulis yang telah membantu dalam proses penyelesaian literatur review ini.

\section{DAFTAR PUSTAKA}

Brastianos, Priscilla K. et al. 2021. "Phase II Study of Ipilimumab and Nivolumab in Leptomeningeal Carcinomatosis." Nature Communications 12(1): 1-7. http://dx.doi.org/10.1038/s41467-02125859-y.

Campbell, Matthew T. et al. 2021. "Pilot Study of Tremelimumab with and without Cryoablation in Patients with Metastatic Renal Cell Carcinoma." Nature Communications 12(1): 1-12.

Cindy Yang, S. Y. et al. 2021. "Pan-Cancer Analysis of Longitudinal Metastatic Tumors Reveals Genomic Alterations and Immune Landscape Dynamics Associated with Pembrolizumab Sensitivity." Nature Communications 12(1): 1-15.

Ding, Mei et al. 2021. "Secretome Screening Reveals Immunomodulating Functions of IFN $\alpha-7$, PAP and GDF-7 on Regulatory T-Cells." Scientific Reports 11(1): $1-13$. https://doi.org/10.1038/s41598-02196184-z.

Dong, Li, Yu Min Zheng, Xiao Guang Luo, and Zhi Yi He. 2021. "High Inflammatory Tendency Induced by Malignant Stimulation through Imbalance of $\mathrm{Cd} 28$ and Ctla-4/Pd-1 Contributes to Dopamine Neuron Injury." Journal of Inflammation Research 14: 2471-82.

Gámez-Díaz, Laura, and Bodo Grimbacher. 2021. "Immune Checkpoint Deficiencies and Autoimmune
Lymphoproliferative Syndromes." Biomedical Journal 4.

Karimi, Mohammad M. et al. 2021. "The Order and Logic of CD4 versus CD8 Lineage Choice and Differentiation in Mouse Thymus." Nature Communications 12(1): 1-14.

Khan, Haroon et al. 2021. "Flavonoids Nanoparticles in Cancer: Treatment, Prevention and Clinical Prospects." Seminars in Cancer Biology 69(June 2019): 200-211. https://doi.org/10.1016/j.semcancer.20 19.07.023.

Rowshanravan, Behzad, Neil Halliday, and David M. Sansom. 2018. "CTLA-4: A Moving Target in Immunotherapy." Blood 131(1): 58-67.

Slingluff, Craig L. et al. 2021. "A Phase 1 Study of NY-ESO-1 Vaccine + AntiCTLA4 Antibody Ipilimumab (IPI) in Patients with Unresectable or Metastatic Melanoma." OncoImmunology 10(1): 1-12. https://doi.org/10.1080/2162402X.202 1.1898105.

Sobhani, Navid et al. 2021. "CTLA-4 in Regulatory $\mathrm{T}$ Cells for Cancer Immunotherapy." Cancers 13(6): 1-18. Sugawara, Kotaro et al. 2021. "Oncolytic Herpes Virus G47A Works Synergistically with CTLA-4 Inhibition via Dynamic Intratumoral Immune Modulation." Molecular Therapy Oncolytics 22(September): 129-42. https://doi.org/10.1016/j.omto.2021.05. 004.

Tian, En ming et al. 2021. "ROR $\gamma$ t Agonist Synergizes with CTLA-4 Antibody to Inhibit Tumor Growth through Inhibition of Treg Cells via TGF- $\beta$ Signaling in Cancer." Pharmacological Research 172(April): 105793. https://doi.org/10.1016/j.phrs.2021.105 793.

Tiemann, Markus, Dmitri Atiakshin, Vera Samoilova, and Igor Buchwalow. 2021.

JBP Vol.23, No.02, Desember 2021- Rian Anggia Destiawan, Anas Fadli Wijaya, M. Elyas Arif Budiman, Septyana Eka Rahmawati DOI 10.20473/jbp.v5i2.2021.49-54 
Jurnal Biosains Pascasarjana Vol. 23 (2021) pp

(C) (2021) Sekolah Pascasarjana Universitas Airlangga, Indonesia "Identification of Ctla-4-Positive Cells in the Human Tonsil." Cells 10(5): 120.

Wu, Xincheng, and Zhengping Bai. 2021. "Multi-Omics Analysis of M6A Modification-Related Patterns Based on M6A Regulators and Tumor Microenvironment Infiltration in Lung Adenocarcinoma." Scientific Reports 11(1): $\quad 1-16$. https://doi.org/10.1038/s41598-02100272-z.

Xiao, Ze Xiu, Joseph S. Miller, and Song Guo Zheng. 2021. "An Updated Advance of Autoantibodies in Autoimmune Diseases." Autoimmunity Reviews 20(2): 102743. https://doi.org/10.1016/j.autrev.2020. 02743. 